\title{
Broad Money Supply and Financial Condition Index for Indian Economy
}

\author{
Sayan Banerjee \\ Economics Area, Institute of Management Technology-Nagpur, 603, Khullar Apartments, Byramji Town, Nagpur-440013, India
}

Copyright $\subset 2017$ by authors, all rights reserved. Authors agree that this article remains permanently open access under the terms of the Creative Commons Attribution License 4.0 International License

\begin{abstract}
In the context of recent global financial crisis, the impact of exogenous shock to the financial sector on the real sector of the economy has come to the notice of the economists all over the world. The traditional dichotomy between financial and real sector is found to be inadequate for either managing or predicting the economy's overall behavior. In view of this recent development, this paper makes an attempt to construct a Financial Condition Index (FCI) in the context of Indian economy, to explore the possibility of how such an index would be an improvement over the traditional Monetary Condition Index (MCI), which has been the central bank's main instrument. The FCI is constructed by incorporating broad money supply along with real interest rate and official exchange rate. Following a weighted sum approach, the index is constructed by taking into consideration macroeconomic data over two decades of time period. The FCI, thus constructed, shows a significant co-relationship with the variability economy's inflation rate, revealing its usefulness as an indicator for early warning system for Indian economy.
\end{abstract}

Keywords Financial Condition Index, Indian Economy, Broad Money Supply

\section{Introduction}

The financial crisis, that hit the economy of USA in 2007, transmitted into an economic slowdown and finally resulted into economic recession. Thereafter, it spread throughout the world and within a year's time most of the major economies entered either into slowdown or stagnation. This financial disruption has been considered as the most serious one since the 'Great Depression' of the early 1930s. For the past few years, the economies across the world are struggling with slow or negative economic growth rate, high unemployment and other evils of economic recession. The unfortunate developments in the world economy have brought to the fore importance of financial sector to macroeconomic outcome. To put it alternatively, there is an increased awareness among economists and policymakers regarding importance of financial sector shocks as a significant source of macroeconomic instability.

In the background of such development, this paper analyzes why an index, that summarizes the financial situation of an economy, better known as Financial Condition Index (FCI), is considered as a useful tool for policy makers and forecasters. The existing practices for construction for FCI are not standardized, and in Indian context such work is few and far between. Given this scenario, the research work explores how some of the existing indexes are constructed and finally undertakes a new econometric research to see how useful a tool FCI could be for analyzing and forecasting business cycles in the context of Indian economy.

\section{Objectives}

Before the financial crisis hit the US economy in 2007, as pointed out by Canuto and Caravallani [1], it was fairly agreed upon among most of the economists and the central banks that economic stability can be ensured by the central bank of a country through twin regimes of inflation targeting and following flexible exchange rate. The close relationship between macroeconomic stability and inflation targeting regime created an atmosphere where financial stability was considered as the job of micro prudential authority or supervisory institution. It was believed that central bank, through its short term interest rate management, could effectively regulate the inflationary pressure and thereby economic stability. The flexible exchange rate, on the other hand, shall take care of shocks to the economy that sourced from the external sector through an automatic adjustment process. No wonder that from the late 80 s the predominant variable that was used by both economist and central banker in keeping a watch over the economic stability were short term interest rate and the exchange rate.

However, a minority of the economists felt that such simple way of persuasion of monetary policy may be missing some of the important aspects of the instability that is built 
within an economy. In an important research paper, Achlain and Klein [2] highlighted the need to incorporate asset prices into measurement of impact of monetary policy as well as designing the same.

The impact of change in the price of house and equity, and thereby the resulting change in wealth of individual was identified by Modigliani[3], who also showed how this 'wealth effect' can have direct impact in the aggregate demand of the economy and thereby create instability. According to Goodhart [4] this provided a theoretical case for incorporating the asset prices and designing and observing the transmission process of the monetary policy in an economy.

A comprehensive approach toward construction of an index which incorporated asset prices, for conduct of monetary policy, was undertaken by Goodhart and Hoffman [5]. They find out that a typical Phillips curve, set up with output and oil price shows a significant negative correlation. They constructed an 'Expanded IS' curve, incorporating interest rate, exchange rate, OECD output, house price and share price. In the context of OECD, their tests show house price effect is stronger than asset price and sometimes even the exchange rate, in explaining inflation variability. It was concluded that this new Financial Condition Index (FCI) is more volatile than that of Monetary Condition Index (MCI), the traditional tool for design of monetary policy.

Another FCI was constructed by David Mayes and Matti Viren [6] in the context of Finland's economy that does not include price of stock in the FCI. This was due to statistical insignificance and also because of the fact that $70 \%$ of Finnish stocks belong to foreigners; therefore no direct link between prices of stock to Finnish wealth. The FCI, constructed by them, Includes price of house to take monetary policy effects into account mode fully. They find that although FCI movements similar to MCI, it is not redundant as it more accurately captures periods of financial volatility.

A. Montaglioni and O. Napolitano[6] in their work finds out inclusions of FCI in Taylor rules provides marginally superior results but FCI doesn't have immediate interpretations, except for asset price have role in interest rate setting because they contain info about future levels of asset price and output.

In a more recent work, Hatzius, Hooper, Mishkin, Schoenholtz and Watson [7] make an attempt to review existing FCIs in the context of financial crisis in the USA. In their NBER working paper they test whether FCIs are useful tool for forecasters in predicting effects of financial conditions on macroeconomic outcomes (if such relationship even exists). Their research paper analyzes how various FCIs are constructed. The paper provides a new tool for construction of FCI as the prior FCIs have 3 problems, namely, "limited time frame, too few indicators and they do not explain monetary policy and business cycle fluctuations".

The existing literature does not highlight any important attempt in development of FCI in the context of Indian economy or how central bank could use asset prices in designing and implementation of monetary policy. However, a paper by R.P. Pradhan [8] explores the nexus between financial development and economic growth in India. Following a vector auto regressive model, he finds out a bidirectional relationship between money supply, market capitalization, foreign trade and economic growth.

In the context of Indian economy, the effective monetary transmission mechanism has been explored by R. Bhattachaya, I. Pathak and A. Shah [9]. The paper identifies that the most effective route through which the mechanism works is through exchange rate.

M. Quazi. and A. Hye [10] make an attempt to link financial development and economic growth in the Indian economy's context. They find out, using an auto regressive distribution lag model (ARDL), a negative relationship between real interest rate in the short and long run with economic growth. Hye concludes such Financial Development Index (FDI) could help policy maintain a parallel financial sector expansion and economic growth.

It can be observed from the above literature review that construction of FCI is not a standardized process as various Institutions and economists follow different approaches. The existing process seem to be broadly categorized in three types, namely, Weighted-sum approach ,Principal Components Analysis (PCA) and Kalman-filter method. This allows for a further experimentation in construction of FCI that could yield better result.

Even though there are a few papers and work done in monetary policy transmission and financial development in the Indian Economy's context, the central bank (RBI) continues to work with MCI as the policy tool; construction of a FCI for India may be useful from the policy perspective.

As the sample period considered in this paper is post liberalization era (post 1990), it attempts at a greater understanding of impact of financial liberalization on the monetary policy and business cycle in India.

The paper is inspired by Goodhart and Hoffman model of weighted sum approach in construction of the FCI. However, it is modified to suit the Indian economy's uniqueness of being a fast growing emerging economy and tries to find out if the approach works in this context as well. In their research work, Goodhart and Hoffman, considered house price and stock prices along with monetary variables of short term interest and exchange rate. In this paper, instead of house price and stock price, $\mathrm{FCI}$ is constructed by incorporating Broad Money Supply, or $\mathrm{M}_{3}$ money supply as it is popularly known. The reason being $M_{3}$ money supply signifies a part of financial condition in India, with a vast percentage of population (especially in rural area) depend on money not as a medium of exchange, but also store of value due to lack of other mainstream financial instruments.

\section{Data}

The paper is developed on the basis of secondary data on 
Indian economy. The data collected for the analysis is for the past 20 years, i.e. from 1995 to 2015.This is because of the fact that from time period of 1995 (post economic liberalization) Indian economy witnessed a sea change in the macroeconomic management with opening up of the economy and transition from fixed to flexible exchange rate. All the data presented in the paper are collected from the open data source of the World Bank.

\section{Methods}

As there is no theoretical underpinning of construction of Financial Condition Index and there has been not much work done in the context of Indian economy, the methodology has been developed on the basis of earlier work done by economists in the context of a different economy. However, this required that the method had to be modified in order to better suit the data availability as well as uniqueness of the Indian economy.

The methodology followed here is one of weighted sum approach of Goodhart and Hoffman, as other methods of construction requires greater volume and higher frequency macroeconomic data, both of which are unfortunately not easily available in Indian economy's context. Moreover, Indian economy till early 1990s was almost a closed and highly regulated economy. Monetary policy was not independently pursued, exchange rate regime was that of a quasi-fixed and the free work of monetary transmission mechanism could not be observed in such circumstances.

Following Goodhart and Hoffman, an IS curve estimate has been explored from the time series data of the past 20 years taking into consideration some of the important variables of immediate interest. Namely, the short term rate official exchanges the rate and the broad money supply. While short term rate and real exchange rate are part of standard Monetary Condition Index (MCI), incorporation of the new variable, the broad money $\left(\mathrm{M}_{3}\right.$ money supply) supply in the equation essentially expands the scope of index to capture the development in the financial sector of the economy. This is due to the fact that Indian economy continues to be the cash driven economy, where currency notes are not just a tool of medium of exchange but an instrument for saving (store of value) as well. Broad money supply is the sum of currency outside banks; demand deposits other than those of the central government; the time, savings, and foreign currency deposits of resident sectors other than the central government; bank and traveler's checks; and other securities such as certificates of deposit and commercial paper (World Bank).

The equation for estimation developed is as follows:

$$
\mathrm{Yt}=\alpha+\beta 1 \mathrm{EXt}+\beta 2 \mathrm{Rt}+\beta 3 \mathrm{Mt}+\mu \mathrm{t}
$$

Where $\mathrm{Yt}=$ Real GDP at the time $\mathrm{t}$

$\mathrm{Rt}=$ Real Rate of Interest (Inflation adjusted short term rate of interest) at time $t$

$\mathrm{EXt}=$ Official Exchange Rate (adjusted against basket of foreign currency)

$\mathrm{Mt}=$ Broad supply of money at time period $\mathrm{t}$.

\section{Construction of the Financial Condition Index}

From the estimate (see table 1), the financial condition index for India has been constructed following weighted sum approach:

$$
\text { FCItzz }=\sum \text { Wit (rit) }
$$

Here the weights (Wit) have been assigned on the basis of relative impact of (rit), which is real rate of interest, official exchange rate and the broad money supply on the aggregate demand. It is important to note here that the weights of real rate of interest (Wr), real exchange rate (Wex) and broad money supply $(\mathrm{Wm})$ adds up to one and has been calculated from the coefficient of equation (1) which equals:

$$
\begin{aligned}
W e x & =|\beta 1| /(|\beta 1|+|\beta 2|+|\beta 3|) \\
W r & =|\beta 2| /(|\beta 1|+|\beta 2|+|\beta 3|) \\
W m & =|\beta 3| /(|\beta 1|+|\beta 2|+|\beta 3|)
\end{aligned}
$$

An FCI that includes asset prices along with short term rate of interest, incorporate better volatility in explaining the inflation rate variation. One of the ways to check for the usefulness of the index constructed is to run a test against the inflation rate. In this paper, consumer price index (CPI) for the time period between 1995 and 2015 has been used for this purpose. The test result (see table 2) shows a significant co-relation exists between the FCI constructed by the researcher and the CPI for the time period of over 20 years. The outcome is heartening as it confirms the usability of FCI as an early warning system for business cycle in Indian economy's context. 


\section{Results}

Table 1. The regression coefficient between Real GDP and Exchange Rate, Rate of Interest and Broad Money supply (1995-2015)

\begin{tabular}{|c|c|c|c|c|c|c|c|c|c|c|}
\hline \multicolumn{11}{|c|}{ Co-efficient } \\
\hline & \multirow{2}{*}{ Model } & \multicolumn{2}{|c|}{$\begin{array}{c}\text { Unstandardized } \\
\text { Coefficients }\end{array}$} & \multirow{2}{*}{$\begin{array}{c}\text { Standardized } \\
\text { Coefficients } \\
\text { Beta }\end{array}$} & \multirow[t]{2}{*}{$\mathrm{t}$} & \multirow{2}{*}{ Sig. } & \multicolumn{2}{|c|}{$\begin{array}{l}95.0 \% \text { Confidence Interval } \\
\text { for B } \\
\end{array}$} & \multicolumn{2}{|c|}{ Collinearity Statistics } \\
\hline & & B & Std. Error & & & & Lower Bound & Upper Bound & Tolerance & VIF \\
\hline \multirow{4}{*}{1} & (Constant) & $3.555 \mathrm{E} 13$ & 7.983E12 & & 4.453 & .000 & $1.863 \mathrm{E} 13$ & $5.247 \mathrm{E} 13$ & & \\
\hline & Exch & 4.882E10 & $2.287 \mathrm{E} 11$ & .014 & .213 & .834 & $-4.361 \mathrm{E} 11$ & 5.337E11 & .191 & 5.246 \\
\hline & $\mathrm{r}$ & $-7.172 \mathrm{E} 11$ & $3.858 \mathrm{E} 11$ & -.067 & -1.859 & .081 & $-1.535 \mathrm{E} 12$ & $1.006 \mathrm{E} 11$ & .629 & 1.591 \\
\hline & M & .754 & .055 & .957 & 13.760 & .000 & .638 & .871 & .169 & 5.900 \\
\hline
\end{tabular}

Dependent Variable: GDP

Source : World Bank Open Data (www.worldbank.org)

Table 2. Correlation between Financial Condition Index (FCI) obtained with Consumer Price Index (CPI): (1995-2015)

\begin{tabular}{|c|c|c|c|}
\hline \multicolumn{2}{|c|}{ Correlations } \\
\hline \multirow{3}{*}{ CPI } & Pearson Correlation & CPI & FCI \\
\cline { 2 - 5 } & Sig. (2-tailed) & 1 & $.523^{*}$ \\
\cline { 2 - 5 } & N & 20 & 2018 \\
\hline \multirow{3}{*}{ FCI } & Pearson Correlation & $.523^{*}$ & 1 \\
\cline { 2 - 4 } & Sig. (2-tailed) & .018 & 20 \\
\hline
\end{tabular}

*. Correlation is significant at the 0.05 level (2-tailed).

CPI Data Source: World Bank Open Data (www.worldbank.org)

\section{Discussion}

Since the time of liberalization of the Indian economy, the financial sector has seen quite a few changes in terms of its growth, operation and greater freedom and innovations. Keeping those factors in mind, it is obvious that managing economy, in terms of implementation of instruments of monetary policy, requires a shift from traditional indicator, such as monetary condition index to a more inclusive financial condition index. The broad money supply, an additional variable that captures the state of the financial sector of the economy with currency availability with the general public, expands the number of variables taken into consideration. The above results obtained seem to confirm the author's believe that such expansion and construction of a new index, would provide a strong co-relationship with inflation rate (which is mainly what monetary policy targets). A change in the broad money supply, can impact the aggregate demand side of the economy, and thus change the inflation rate in it. Incorporation of broad money supply captures the developments in the commercial banking sector as well the financial transaction that are essentially driven by currency notes. A change in the broad money supply shall be reflected in the value of the index. It could be used as an early warning signal for volatality in the inflation rate in the economy. This may be useful in managing the stability in the economy as the central bankers would be able to implement effective instruments to achieve their targets in appropriate time period.

\section{Conclusions}

Reserve Bank of India (RBI), which is the central bank of the country, pursues its monetary policy with explicit inflation targeting. In doing so, it uses Monetary Condition Index (MCI), constructed by incorporating real rate of interest (short term) and the real exchange rate. This instrument is utilized with an implicit believe that apart from these two, other financial variables (asset prices) are not relevant as far as their impact on the real economy is concerned. However, given the recent developments, such belief systems need to be changed. A financial index, instead of a monetary index should be considered as more effective instruments since it consists of additional asset prices that summarize the overall financial condition of the economy. This paper constructed one such by incorporating broad money supply along with short term rate and official exchange rate. Indian economy, which did not see an independent monetary policy being pursued till very recently (late 90s), has now emerged as one of the fast growing economy, where financial sectors play an ever increasing role in both growth of the economy as well as volatility in it. Incorporation of broad money supply, therefore, brings into the picture the role of financial sector and the external shocks it may receive from time to time on the real macroeconomic variables. The strong co-relation between FCI and CPI seems to prove the impact that financial sector has on the real sector of the economy. Even when there is a lack of data 
availability and the series taken into consideration is relatively short, it is still heartening that a FCI constructed using an important asset price namely, short term rate, official exchange rate and broad money supply, could generate a well-functioning tool that can be utilized as an early warning tool to deal with business cycle and enable the central bank to design its monetary policy accordingly.

\section{REFERENCES}

[1] Canuto O, Carvallani M. Asset Prices, Macroprudential Regulation and Monetary Policy. World Bank research Paper, Washington D.C.; 2013. Volume 6310.

[2] Alchain A, Klein B. On A Correct Measure of Inflation. Journal of Money, Credit and Banking, Ohio State University; 1973. Vol.5, part 1, No.1.

[3] Montaglioni A, Napolitano O. Financial Conditions Index and Interest Rate Settings: A Comparative Analysis. Istituto di Studi Economici Working Paper Series; 2004. Volume 8.2005 .

[4] Goodhart C, Hofmann B. Asset Prices, Financial Conditions, and the Transmission of Monetary Policy. Stanford University, Conference on Asset Prices, Exchange Rates and Monetary Policy; 2001.

[5] Goodhart C, Hofmann B. Asset Prices and the Conduct of Monetary Policy. Mimeo, London School of Economics; 2002.

[6] Mayes D, Viren M. Financial Conditions Indexes. Bank of Finland Discussion Papers; 2001.Volume 17/2001.

[7] Hatzius, J. Hooper, P, Mishkin F S, Schoenholtz K L, Watson M W. Financial Conditions Indexes: A Fresh Look after the Financial Crisis. National Bureau of Economic Research Working Paper; 2010. Volume 16150.

[8] Pradhan R P. The Nexus between Financial Development Index and Economic Growth in India: Evidence from Multivariate VAR Model. International Journal of Research and Review in Applied Sciences; 2009. Volume I, Issue 2.

[9] Bhattacharya R, Patnaik I, Shah A. Monetary Policy Transmission in an Emerging Market Setting. National Institute of Public Finance and Policy, New Delhi; 2011. Working paper 2011-78.

[10] Quazi M, Hye A. Financial Development Index and Economic Growth: Empirical Evidence from India. Journal of Risk Finance; 2011.Volume12, No. 2. 